Jurnal Akuakultur Sungai dan Danau Vol. 1 No. 1 Tahun 2016 Hal 22 - 31

ISSN Online 2503-4766

\title{
PERBEDAAN DEBIT AIR PADA SISTEM RESIRKULASI TERHADAP KELANGSUNGAN HIDUP LARVA IKAN LELE DUMBO (Clarias gariepinus B)
}

\author{
Muarofah Ghofur ${ }^{1}$, M. Sugihartono ${ }^{2}$, Julianto $^{3}$ \\ ${ }^{1}$ Dosen Program Studi Budidaya Perairan, ${ }^{2}$ Dosen Program Studi Budidaya Perairan, \\ ${ }^{3}$ Mahasiswa Program Studi Budidaya Perairan
}

Program Studi Budidaya Perairan, Fakultas Pertanian, Universitas Batanghari

Jalan Slamet Riyadi, Broni, Jambi 36122, Telp. +62074160103

1 email korespondensi: muarofah_ghofur@yahoo.com

\begin{abstract}
This study aimed to obtain of survival rate and growth for catfish larvae were mainten in recirculation system with different water discharge. Benefit of this research are increase to aquaculture production especially catfish larvae.

The experiment was conducted on March to August 2016 in Regional Technical Implementation Unit Taman Anggrek Telanaipura Subdistrict of Jambi Province. This study used Random Design Analisys with 4 treatments and 3 replicates respectively treatment A: without circulation (control), treatment B: $10 \mathrm{ml} / \mathrm{sec}$ of water, treatment $C: 20 \mathrm{ml} / \mathrm{sec}$ of water, treatment D: 30 $\mathrm{ml} / \mathrm{sec}$ of water.

The parameter were observated of Survival rate and Water Quality. The data have been obtained were tabulated and analyzed in accordance with the perpose of research, and then analysis of variance (ANOVA) at the $95 \%$ confidence interval.

The result showed that different water discharge significant effect on survival rate catfish larvae. Percent of best survival rate for catfish larvae amounted to $95.33 \%$ at the discharge of water $30 \mathrm{ml} / \mathrm{sec}$ (treatment $\mathrm{D}$ ).
\end{abstract}

Keywords: Water Discharge, Recirculation System, Survival Rate, Catfish

\begin{abstract}
Abstrak
Tujuan penelitian ini adalah mengetahui tingkat kelangsungan hidup dan pertumbuhan larva Ikan Lele Dumbo (C. gariepinus.B) yang dipelihara dalam sistem resirkulasi dengan debit air yang berbeda. Adapun manfaat dari kegiatan ini adalah untuk meningkatkan hasil produksi perikanan terutama dari komoditas ikan lele dumbo (C.gariepinus.B).

Penelitian ini rencananya akan dilaksanakan pada bulan Maret sampai bulan Agustus tahun 2016 di Unit Pelaksana Teknis Daerah Instalasi Taman Angrek Kecamatan Telanaipura Provinsi Jambi. Penelitian yang dilakukan menggunakan rancangan lingkungan Rancangan Acak Lengkap (RAL) dengan 4 (empat) perlakuan dan 3 (tiga) ulangan, masing - masing perlakuan tersebut adalah :perlakuan A : tanpa sirkulasi ( kontrol ), perlakuan B : 10 ml/detik air, perlakuan $\mathrm{C}: 20 \mathrm{ml} /$ detik air, perlakuan $\mathrm{D}: 30 \mathrm{ml} /$ detik air.

Parameter penelitian yang diamati adalah: Tingkat Kelangsungan Hidup Ikan dan Kualitas Air. Data yang telah diperoleh kemudian ditabulasi dan dianalisis sesuai dengan tujuan penelitian, kemudian dilakukan analisis ragam (ANOVA) pada selang kepercayaan 95\%.

Hasil penelitian menunjukkan bahwa perbedaan debit air memberikan pengaruh nyata terhadap kelangsungan hidup larva ikan lele dumbo. Persentase kelangsungan hidup yang terbaik untuk larva ikan lele dumbo adalah sebesar 95,33\% pada debit air $30 \mathrm{ml} /$ detik (perlakuan D).
\end{abstract}

Kata kunci : Debit Air, Sistem Resirkulasi, Kelangsungan Hidup, Ikan Lele Dumbo 


\section{PENDAHULUAN}

Pemeliharaan larva ikan lele dumbo (C. gariepinus. B) merupakan tahapan yang paling kritis pada siklus hidupnya karena tingkat mortalitasnya paling tinggi, salah satu faktor penting dalam perawatan larva adalah pengelolaan kualitas air. Penurunan kualitas air atau kualitas air yang buruk dapat mengakibatkan ikan menjadi stress sehingga mudah terserang penyakit bahkan dapat menyebabkan kematian. Upaya yang dapat dilakukan terkait hal tersebut dengan menjaga kualitas air didalam media pemeliharaan larva ikan lele dumbo (C. gariepinus. $B$ ).

Sistem resirkulasi merupakan salah satu cara untuk memperbaiki kualitas air, membantu distribusi oksigen ke segala arah, dan dapat menjaga akumulasi atau mengumpulnya hasil metabolisme beracun sehingga kadar atau daya racun dapat dikurangi dalam media pemeliharaan (Kelabora dan Sabariah,2010).

Pada perawatan larva, agar larva tidak terbawa arus dan tidak hanyut sebaiknya arus air dan pergerakan air tidak terlalu deras salah satu caranya dengan mengatur debit air yang masuk pada tempat perawatan larva, namun dalam hal ini belum diketahui pasti debit air yang optimal untuk perawatan larva ikan lele dumbo (Kelabora dan Sabariah, 2010)

Berlatar belakang dari penjelasan di atas penulis tertarik melakukan penelitian tentang "Tingkat Kelangsungan Hidup Dan Pertumbuhan Larva Ikan Lele Dumbo (C. gariepinus. B) Dengan Debit Air Yang Berbeda Pada Sistem Resirkulasi”. Hipotesis

Berdasarkan penelitian yang akan dilakukan, maka hipotesisnya adalah :

H0 : Tidak ada pengaruh Tingkat Kelangsungan Hidup Dan Pertumbuhan Larva Ikan Lele Dumbo (C. gariepinus. B) Dengan Debit Air Yang Berbeda Pada Sistem Resirkulasi.

H1 : Ada pengaruh Tingkat Kelangsungan Hidup Dan Pertumbuhan Larva Ikan Lele Dumbo (C. gariepinus.B) Dengan Debit Air Yang Berbeda Pada Sistem Resirkulasi.

\section{TUJUAN}

Tujuan penelitian ini adalah mengetahui tingkat kelangsungan hidup dan pertumbuhan larva Ikan Lele Dumbo (C. gariepinus. $B)$ yang dipelihara dalam sistem resirkulasi dengan debit air yang berbeda.

\section{Waktu dan Tempat Penelitian}

\section{METODOLOGI PENELITIAN}

Penelitian ini rencananya akan dilaksanakan pada bulan Maret sampai bulan Agustus tahun 2016 di Unit Pelaksana Teknis Daerah Instalasi Taman Angrek Kecamatan Telanaipura Provinsi Jambi.

\section{Alat dan Bahan}

Adapun alat yang digunakan dalam pelaksanaan penelitian ini antara lain : akuarium, pompa air, blower, mangkok putih, serok halus, pipa paralon, keran air, literan air, baskom, selang sifon, alat pengukur kualitas air, timbangan digital, alat tulis, kamera digital, mistar, genset.

Bahan yang akan digunakan adalah benih ikan lele dumbo sebanyak 1.000 ekor dari induk yang sama yaitu hasil pemijahan secara alami di Instalasi Taman Anggrek. 
Jurnal Akuakultur Sungai dan Danau Vol. 1 No. 1 Tahun 2016 Hal 22 - 31

ISSN Online 2503-4766

\section{Rancangan penelitian}

Penelitian yang dilakukan menggunakan rancangan lingkungan Rancangan Acak Lengkap (RAL) dengan 4 (empat) perlakuan dan 3 (tiga) ulangan, masing - masing perlakuan tersebut adalah :

1. Perlakuan A : Tanpa sirkulasi ( kontrol )

2. Perlakuan B : $10 \mathrm{ml} /$ detik air

3. Perlakuan $\mathrm{C}: 20 \mathrm{ml} /$ detik air

4. Perlakuan D : $30 \mathrm{ml} /$ detik air

\section{Parameter yang Diamati}

\section{Tingkat Kelangsungan Hidup Ikan}

Setelah penelitian selesai, dilakukan penghitungan kelangsungan hidup benih dengan cara menghitung jumlah benih yang hidup dan yang mati. Adapun rumus yang digunakan untuk menghitung Survival Rate menurut Effendi (1979) adalah:

$$
\mathrm{SR}=\frac{N t}{N o} \times 100 \%
$$

Keterangan :

$$
\begin{array}{ll}
\mathrm{SR} & =\text { Kelangsungan Hidup (\% ) } \\
\mathrm{Nt} & \text { = Jumlah ikan yang hidup pada akhir pemeliharaan (ekor) } \\
\mathrm{No} & \text { = Jumlah ikan yang hidup pada awal pemeliharaan (ekor). }
\end{array}
$$

- Rumus Menentukan debit

Debit air adalah kecepatan aliran air per satuan waktu.

$$
\mathrm{Q}=\mathrm{V} / \mathrm{t}
$$

$$
\begin{aligned}
& \text { Keterangan : } \\
& \begin{aligned}
\mathrm{Q} & =\text { Debit }(\mathrm{ml} / \mathrm{s}) \\
\mathrm{V} & =\text { Volume air }(\mathrm{ml}) \\
\mathrm{t} & =\text { Waktu }(\mathrm{s})
\end{aligned}
\end{aligned}
$$

\section{Kualitas Air}

Pengukuran kualitas air yang akan dilakukan sebanyak 2 kali yaitu pada awal dan akhir penelitian. Pengecekan kualitas air akan dilakukan di Balai Laboratorium Fakultas Pertanian Universitas Batanghari Jambi. Sedangkan parameter kualitas air yang diamati dalam penelitian ini dapat dilihat pada Tabel 2, dibawah ini :

Tabel 1. Parameter kualitas air dan metode pengamatan percobaan

\begin{tabular}{ccc}
\hline No & Parameter & Metode Pengamatan \\
\hline 1 & Suhu $\left({ }^{0} \mathrm{C}\right)$ & Thermometer \\
2 & $\mathrm{pH}$ & $\mathrm{pH}$ meter \\
3 & $\mathrm{DO}(\mathrm{ppm})$ & DO meter \\
4 & $\mathrm{CO}_{2}(\mathrm{ppm})$ & Titrasi (winkler) \\
5 & Amonia $(\mathrm{ppm})$ & Spektrofometer \\
\hline
\end{tabular}

\section{Analisis Data}

Data yang telah diperoleh kemudian ditabulasi dan dianalisis sesuai dengan tujuan penelitian. Data parameter derajat kelangsungan hidup, pertumbuhan berat dan 
Jurnal Akuakultur Sungai dan Danau Vol. 1 No. 1 Tahun 2016 Hal 22 - 31

ISSN Online 2503-4766

pertumbuhan panjang dianalisis menggunakan analisis ragam (ANOVA) pada selang kepercayaan 95\%. Analisis ini digunakan untuk menentukan apakah perlakuan berpengaruh nyata terhadap derajat kelangsungan hidup, pertumbuhan berat dan pertumbuhan panjang. Apabila berpengaruh nyata, untuk melihat perbedaan antar perlakuan akan diuji lanjut menggunakan uji Tukey. Analisis deskripsi kuantitatif berupa tabel digunakan untuk menjelaskan kelayakan media pemeliharaan bagi kehidupan benih ikan lele dumbo selama penelitian. Analisis data menggunakan perangkat lunak Ms.Excel 2007 dan SPSS 16.0.

\section{HASIL DAN PEMBAHASAN \\ Kelangsungan Hidup Larva Ikan Lele Dumbo (C. gariepinus.B)}

Berdasarkan hasil penelitian tingkat kelangsungan hidup dan pertumbuhan larva ikan lele dumbo (C. gariepinus. B), menggunakan metode resirkulasi dengan debit air yang berbeda, pada setiap perlakuan dan ulangan yang dilaksanakan selama 40 hari, didapatkan perbedaan jumlah kelangsungan hidup larva ikan lele dumbo $(C$. gariepinus.B). Jumlah kelangsungan hidup larva ikan lele dumbo (C. gariepinus. $B$ ) selama penelitian disajikan pada pada tabel 3.

Tabel 2. Tingkat Kelangsungan Hidup ikan lele (C. gariepinus.B) pada debit air yang berbeda selama masa pemeliharaan

\begin{tabular}{lc}
\hline \multicolumn{1}{c}{ Perlakuan } & Rata - rata kelangsungan hidup (\%) \\
\hline A (Tanpa Resirkulasi) & $56.45^{\mathrm{a}}$ \\
B (10 ml/detik) & $89.15^{\mathrm{b}}$ \\
C (20 ml/detik) & $94.21^{\mathrm{b}}$ \\
D (30 ml/detik) & $95.33^{\mathrm{b}}$
\end{tabular}

Keterangan : Angka - angka yang diikuti oleh huruf yang berbeda menunjukkan perlakuan berbeda nyata pada Uji BNJ taraf $5 \%$.

Tabel diatas menunjukkan bahwa pada perlakuan $\mathrm{D}$ (30 ml/detik), memberikan rata - rata kelangsungan hidup larva ikan lele dumbo (C. gariepinus. B) yang paling tinggi dengan persentase $95.33 \%$, kemudian diikuti perlakuan perlakuan $\mathrm{C}$ ( $20 \mathrm{ml} /$ detik $)$ dengan persentase kelangsungan hidup $94.21 \%$, dilanjutkan dengan perlakuan B (10 $\mathrm{ml} /$ detik) dengan persentase kelangsungan hidup $89.15 \%$ dan perlakuan A (tanpa sirkulasi) dengan persentase kelangsungan hidup 56.45\%. Berdasarkan analisis sidik ragam (ANOVA), pemeliharaan lele dumbo (C. gariepinus. $B$ ) dengan sistem resirkulasi berpengaruh nyata $(\mathrm{P}<0.5)$.

Untuk mengetahui tingkat kelangsungan hidup larva ikan lele dumbo $(C$. gariepinus. $B$ ) dapat dilihat pada gambar grafik berikut ini:

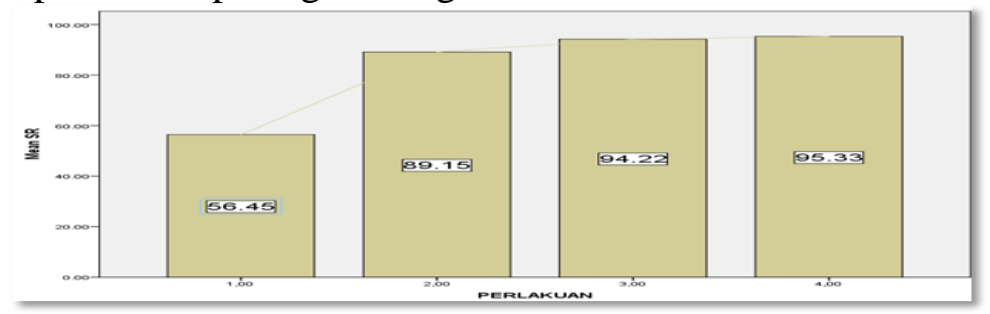

Gambar 1. Grafik Kelangsungan Hidup Larva Ikan lele dumbo (C. gariepinus. B). 
Data hasil penelitian ini menunjukkan bahwa pemeliharaan larva ikan lele dumbo yang paling baik yaitu perlakuan $\mathrm{D}(30 \mathrm{ml} / \mathrm{detik})$, memberikan rata - rata kelangsungan hidup larva ikan lele dumbo (C. gariepinus. $B$ ) yang paling tinggi dengan persentase $95.33 \%$. Tingginya kelangsungan hidup pada perlakuan D diduga karena pada debit air yang tinggi, kandungan oksigen terlarut menjadi tinggi, oksigen terlarut dalam air sangat essensial bagi ikan untuk bernafas dan merupakan komponen utama dalam proses metabolisme. Sementara rendahnya kadar oksigen dapat berpengaruh terhadap fungsi biologis dan lambatnya pertumbuhan dan perkembangbiakan ikan, bahkan hal tersebut dapat berakibat kematian.

Menurut Afrianto dan Liviawaty (1988) debit air yang terlalu rendah akan mengakibatkan produksi ikan menurun kandungan oksigen didalam air menjadi berkurang dan sisa makanan atau kotoran hasil metabolisme tidak segera terbuang. Menurut Zonneveld, et al. (1991) mengatakan kualitas air yang baik akan mempengaruhi kelangsungan hidup dan pertumbuhan ikan. Semetara untuk tingkat kelangsungan hidup terendah terjadi pada perlakuan A (Tanpa resirkulasi) dengan persentase kelangsungan hidup $56.45 \%$ hal ini terjadi kandungan oksigen terlarut pada perlakuan A tidak sesuai dengan kebutuhan larva. Menurut Hidayat (2008) bahwa kandungan oksigen terlarut dalam air merupakan faktor yang penting bagi kehidupan ikan dan organisme akuatik lainnya.

\section{Pertumbuhan Larva Ikan Lele Dumbo (C. gariepinus.B)}

Berdasarkan hasil penelitian tingkat kelangsungan hidup dan pertumbuhan larva ikan lele dumbo (C. gariepinus. B), menggunakan metode resirkulasi dengan debit air yang berbeda, pada setiap perlakuan dan ulangan yang dilaksanakan selama 40 hari, didapatkan perbedaan pertumbuhan larva ikan lele dumbo (C. gariepinus.B). Pertumbuhan panjang dan berat larva ikan lele dumbo (C. gariepinus.B) selama penelitian disajikan pada tabel 4 dan tabel 5 seperti berikut ini :

Tabel 3. Pertambahan Panjang ikan lele dumbo (C. gariepinus.B) pada debit air yang berbeda selama masa pemeliharaan

\begin{tabular}{lc}
\hline \multicolumn{1}{c}{ Perlakuan } & Rata - rata Pertambahan Panjang (cm) \\
\hline A (Tanpa Resirkulasi) & $2.291^{\mathrm{a}}$ \\
B (10 ml/detik) & $2.727^{\mathrm{ab}}$ \\
C (20 ml/detik) & $2.800^{\mathrm{ab}}$ \\
D (30 ml/detik) & $2.978^{\mathrm{b}}$ \\
\hline Keterangan : Angka - angka yang diikuti oleh huruf yang berbeda menunjukkan \\
perlakuan berbeda nyata pada Uji BNJ taraf $5 \%$.
\end{tabular}

Tabel 4. Pertambahan Berat ikan lele dumbo (C. gariepinus.B) pada debit air yang berbeda selama masa pemeliharaan

\begin{tabular}{lc}
\hline \multicolumn{1}{c}{ Perlakuan } & Rata - rata Pertambahan Berat $(\mathbf{g})$ \\
\hline A (Tanpa Resirkulasi) & $1.074^{\mathrm{a}}$ \\
B (10 ml/detik) & $2.004^{\mathrm{b}}$ \\
C (20 ml/detik) & $2.072^{\mathrm{b}}$ \\
D (30 ml/detik) & $2.078^{\mathrm{b}}$ \\
\hline
\end{tabular}


Jurnal Akuakultur Sungai dan Danau Vol. 1 No. 1 Tahun 2016 Hal 22 - 31

ISSN Online 2503-4766

Keterangan : Angka - angka yang diikuti oleh huruf yang berbeda menunjukkan perlakuan berbeda nyata pada Uji BNJ taraf $5 \%$.

Tabel diatas menunjukkan bahwa pada perlakuan $\mathrm{D}$ (30 ml/detik), memberikan rata - rata pertambahan panjang dan berat larva ikan lele dumbo (C. gariepinus.B) yang paling tinggi dengan pertambahan panjang $2.978 \mathrm{~cm}$ dan pertambahan berat 2.078 gram. Kemudian diikuti perlakuan C (20 ml/detik) dengan pertambahan panjang 2.800 $\mathrm{cm}$ dan pertambahan berat 2.072, dilanjutkan dengan perlakuan $\mathrm{B}(10 \mathrm{ml} /$ detik $)$ dengan pertambahan panjang $2.727 \mathrm{~cm}$ dan pertambahan berat 2.004 gram, dan perlakuan A (tanpa sirkulasi) dengan pertambahan panjang $2.291 \mathrm{~cm}$ dan pertambahan berat 1.074 gram. Berdasarkan ANOVA, pemeliharaan larva lele dumbo (C. gariepinus. $B)$ dengan sistem resirkulasi berpengaruh tidak nyata $(\mathrm{P}<0.5)$ terhadap pertambahan panjang dan berpengaruh nyata $(\mathrm{P}>0.5)$ terhadap pertambahan berat.

Untuk mengetahui tingkat pertambahan panjang larva ikan lele dumbo

$(C$. gariepinus. B) dapat dilihat pada gambar grafik berikut ini:

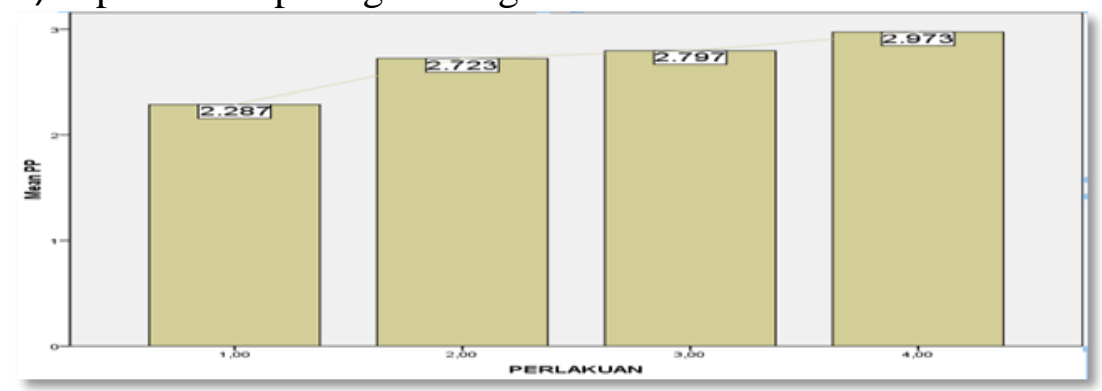

Gambar 2. Grafik Pertambahan Panjang Larva Ikan lele dumbo (C. gariepinus.B)

Sementara untuk mengetahui tingkat pertambahan berat larva ikan lele dumbo (C.gariepinus.B) dapat dilihat pada gambar grafik berikut ini.

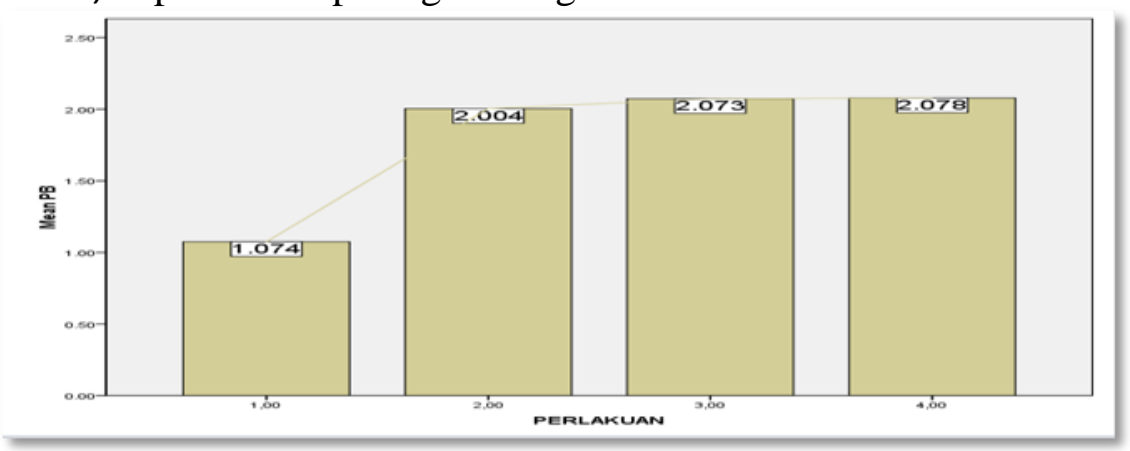

Gambar 3. Grafik Pertambahan Berat Larva Ikan lele dumbo (C. gariepinus. B)

Data hasil penelitian ini menunjukkan bahwa pemeliharaan larva ikan lele dumbo (C. gariepinus. $B)$ yang paling baik yaitu perlakuan D (30 $\mathrm{ml} /$ detik $)$, memberikan rata - rata pertambahan panjang dan berat larva ikan lele dumbo (C. gariepinus.B) yang paling tinggi dengan pertambahan panjang $2.978 \mathrm{~cm}$ dan pertambahan berat 2.078 gram. Tingginya pertambahan panjang dan berat pada perlakuan $\mathrm{D}$ diduga pada perlakuan D memiliki kandungan oksigen terlarut yang paling tinggi, sehingga aktivitas ikan dapat berjalan dengan baik.

Wardoyo dalam Hidayat (2008), menyatakan bahwa agar kehidupan ikan dapat layak dan kegiatan perikanan berhasil, maka kandungan oksigen terlarut tidak boleh kurang dari $4 \mathrm{mg} / \mathrm{l}$. 
Jurnal Akuakultur Sungai dan Danau Vol. 1 No. 1 Tahun 2016 Hal 22 - 31

ISSN Online 2503-4766

\section{Parameter Kualitas Air}

Didalam pelaksanaan penelitian ini, ada beberapa parameter kualitas air yang diamati diantaranya suhu, $\mathrm{pH}, \mathrm{DO}, \mathrm{CO}_{2}$ dan Amoniak. Untuk pengamatan suhu, $\mathrm{DO}$ dan $\mathrm{pH}$, dilakukan dilokasi penelitian yaitu Instalasi Perikanan Taman Anggrek. Sementara untuk pengujian amoniak dan karbondioksida dilakukan dilaboratorium dasar Universitas Batanghari Jambi. Hasil dari pengukuran parameter kualitas air selama penelitian dapat dilihat pada tabel 6 .

Tabel 5. Kisaran kualitas air media pemeliharaan ikan lele dumbo (C. gariepinus.B) selama masa pemeliharaan

\begin{tabular}{|c|c|c|c|c|c|c|c|c|c|}
\hline \multirow{2}{*}{$\begin{array}{c}\text { Parameter } \\
\text { Kualitas } \\
\text { Air }\end{array}$} & \multicolumn{4}{|c|}{ Sebelum penelitian } & \multicolumn{4}{|c|}{ Sesudah Penelitian } & \multirow[b]{2}{*}{ Kisaran Optimal } \\
\hline & $\mathbf{A}$ & B & $\mathrm{C}$ & D & $\mathbf{A}$ & B & $\mathbf{C}$ & D & \\
\hline Suhu $\left({ }^{0} \mathrm{C}\right)$ & $28^{0} \mathrm{C}$ & $28^{0} \mathrm{C}$ & $28^{0} \mathrm{C}$ & $28^{0} \mathrm{C}$ & $28^{0} \mathrm{C}$ & $28^{0} \mathrm{C}$ & $28^{0} \mathrm{C}$ & $28^{0} \mathrm{C}$ & $\begin{array}{l}26-28^{\circ} \mathrm{C} \text { (Tai } e t \\
\text { al., 1979). }\end{array}$ \\
\hline $\mathbf{P h}$ & 6,5 & 6,5 & 6,5 & 6,5 & 6,5 & 6,5 & 6,5 & 6,5 & $\begin{array}{l}6,9 \text { - 7,0 } \\
\text { Zonneveld (1991), }\end{array}$ \\
\hline DO (ppm) & 4,83 & 4,87 & 4,77 & 4,17 & 4,20 & 6,20 & 5,27 & 6,50 & $\begin{array}{l}>4 \text { (Hidayat, } \\
\text { 2008). }\end{array}$ \\
\hline $\begin{array}{l}\mathrm{CO}_{2} \\
(\mathrm{ppm})\end{array}$ & 7.21 & 7.21 & 7.21 & 7.21 & 2.45 & 7.99 & 10,35 & 9.23 & $\begin{array}{l}<12 \mathrm{ppm}(\mathrm{Pescod}, \\
1973 \text { dalam } \\
\text { Setianawaty,2005) }\end{array}$ \\
\hline $\begin{array}{l}\text { Ammonia } \\
\text { (ppm) }\end{array}$ & 0,011 & 0,011 & 0,011 & 0,011 & 0,017 & 0,024 & 0,035 & 0,021 & $\begin{array}{l}<0,1 \text { (Yamagata } \\
\text { dan Niwa 1982) }\end{array}$ \\
\hline
\end{tabular}

Suhu media pemeliharaan ikan lele selama penelitian berkisar antara $27^{\circ} \mathrm{C}$ $28^{\circ} \mathrm{C}$ (Tabel 6) sehingga masih dalam kisaran normal (Tai et al. 1979). Semakin tinggi suhu, maka laju metabolism semakin tinggi. Suhu merupakan salah satu faktor fisika perairan yang sangat penting dan berpengaruh bagi pertumbuhan ikan. Ikan merupakan hewan berdarah dingin sehingga suhu berpengaruh langsung pada laju metabolisme ikan.

Perubahan suhu dapat menyebabkan perubahan laju metabolisme ikan, semakin tinggi suhu media maka laju metabolisme ikan juga akan meningkat sehingga nafsu makan ikan meningkat. Sistem resirkulasi merupakan aplikasi proses perbaikan kualitas air secara langsung, perlakuan resirkulasi dan resirkulasi pada penelitian ini memiliki kisaran suhu yang hampir sama, hal ini diduga kondisi lingkungan budidaya indor yang menyebabkan fluktuasi suhu dapat diminimalisir. Menurut Effendie (2003), perubahan suhu melebihi $3-4^{0} \mathrm{C}$ akan menyebabkan perubahan metabolisme yang mengakibatkan kejutan suhu, meningkatkan toksinitas kontaminan yang terlarut, menurunkan DO dan meningkatkan kematian pada ikan.

Keasaman $(\mathrm{pH})$ yang suboptimal berakibat buruk pada spesies kultur dan menyebabkan ikan stres, mudah terserang penyakit, produktivitas dan pertumbuhan rendah. Batas toleransi ikan terhadap $\mathrm{pH}$ adalah bervariasi tergantung suhu, kadar oksigen terlarut, alkalinitas, adanya ion dan kation, serta siklus hidup organisme tersebut (Pescond 1973 dalam Rohaedi 2002). Derajat keasaman ( $\mathrm{pH}$ ) selama penelitian rata - rata 6.5 kisaran ini masih berada pada kisaran yang optimum dalam budidaya ikan. Zonneveld (1991), menyatakan bahwa untuk kegiatan budidaya ikan yang baik harus mempunyai nilai $\mathrm{pH}$ antara 6,9 sampai 7,0. Selain itu sistem resirkulasi terbukti dapat memberikan kestabilan $\mathrm{pH}$ media budidaya, hal ini terlihat dari parameter kualitas 
air yang berhubungan langsung dengan $\mathrm{pH}$ juga mengalami kestabilan dengan tingkat fluktuasi yang sangat rendah. Air yang masuk kembali ke media pemeliharaan sudah mengalami proses filterisasi fisik, kimia, dan biologi sehingga memiliki kualitas yang baik.

Kandungan oksigen terlarut sebelum penelitian untuk masing-masing perlakuan A,B,C,D sebesar 4,83 ppm; 4,87 ppm; 4,77 ppm; 4,17 ppm. Kandungan oksigen ini meningkat setelah masa pemeliharaan pada perlakuan B,C,D dan menurun pada perlakuan A sebesar 4,20 ppm; 6,20 ppm; 5,27 ppm; 6,50 ppm. Rata-rata pertambanhan kandungan oksigen perlakuan B,C,dan D sebesar 2 ppm kisaran ini masih berada dalam kisaran yang mendukung untuk kehidupan ikan (Hidayat, 2008). Wardoyo dalam Hidayat (2008), menyatakan bahwa agar kehidupan ikan dapat layak dan kegiatan perikanan berhasil, maka kandungan oksigen terlarut tidak boleh kurang dari $4 \mathrm{mg} / \mathrm{l}$. Penurunan kandungan oksigen pada perlakuan A diduga karena meningkatnya kandungan amoniak sehingga bakteri menggunakan oksigen lebih banyak untuk merombak senyawa toksik tersebut. Sehingga kandungan oksigen terlarut yang ada digunakan bersama-sam oleh ikan dan bakteri menyebabkan kandungan oksigen turun.

Nilai korbondioksida bebas selama penelitian berkisar antara antara $2.45 \mathrm{mg} / \mathrm{l}-$ $10.35 \mathrm{mg} / \mathrm{l}$ nilai ini masih dalam kondisi yang normal untuk pertumbuhan larva ikan lele dumbo. Menurut Kordi dalam effendi (2000), karbondioksida merupakan hasil buangan akibat adanya proses pernafasan mahkluk hidup. Nilai karbondioksida $\left(\mathrm{CO}_{2}\right)$ terlarut dalam air ditentukan/dipengaruhi oleh nilai $\mathrm{pH}$ dan suhu. Jumlah karbondioksida dalam air yang bertambah akan menekat aktifitas pernafasan ikan dan menghambat pengikatan oksigen oleh hemoglobin sehingga dapat membuat ikan menjadi stress. Kualitas air yang dihasilkan selama penelitian masih layak untuk kegiatan pendederan ikan gurame, dikarenakan sistem pengelolaan air yang digunakan adalah sistem resirkulasi.

Menurut Timmons dan Losordo (1994) sistem resirkulasi adalah suatu wadah pemeliharaan ikan yang menggunakan sistem perputaran air, yang mengalirkan air dari wadah pemeliharaan ikan ke wadah filter (treatment), lalu dialirkan kembali ke wadah pemeliharaan sehingga kualitas air tetap terkontrol. Sistem resirkulasi memberikan perbaikan kualitas air karena memungkinkan terjadinya dua proses ekologi yaitu konsumsi dan dekomposisi. Proses dekomposisi meliputi: sedimentasi, filtrasi dan aerasi. Konsentrasi amoniak selama penelitian berkisar antara 0,0011 - 0,0035 mg/l, kisaran ini masih berada dalam konsentrasi yang bisa ditolerir oleh ikan. Diduga karena pada saat penetasan tidak terjadi proses metabolisme. Menurut Zonneveld (1991), amoniak meupakan hasil akhir dari proses metabolisme protein.

Amonia yang berkurang dalam penelitian ini disebabkan kinerja dari filtrasi biologi dan filtrasi kimia. Biofilter memiliki peran yang sangat penting dalam sistem resirkulasi. Stickney (1993) menyatakan, bahwa biofilter menyediakan area permukaan untuk tumbuhnya koloni bakteri yang mendetoksifikasi hasil metabolisme ikan melalui fungsi utama biofilter adalah mengubah amoniak menjadi nitrit $\left(\mathrm{NO}_{2}\right)$ yang kemudian diubah menjadi nitrat $\left(\mathrm{NO}_{3}\right)$ yang relatif tidak berbahaya. Bakteri Nitrosomonas dan Nitrobacter membantu dalam merubah nitrit menjadi nitrat, kemudian dengan adanya filter kimia akan membantu dalam perbaikan kualitas air khususnya amonia. Menurut Spotte (1997) fungsi filter kimia adalah membersihkan molekul-molekul bahan anorganik terlarut melalui proses oksidatif atau penyerapan langsung. Kualitas air yang terjaga selama pemeliharaan sangat membantu dalam kehidupan dan pertumbuhan benih ikan lele dumbo (C. gariepinus. B). 
Jurnal Akuakultur Sungai dan Danau Vol. 1 No. 1 Tahun 2016 Hal 22 - 31

ISSN Online 2503-4766

\section{KESIMPULAN}

Berdasarkan hasil penelitian tingkat kelangsungan hidup dan pertumbuhan larva ikan lele dumbo (C. gariepinus. B) menggunakan metode resirkulasi dengan debit air yang berbeda memberikan pengaruh yang nyata terhadap kelangsungan hidup dan pertumbuhan berat larva lele dumbo (C. gariepinus. $B$ ) sementara untuk pertumbuhan panjang tidak memberikan pengaruh yang nyata. Untuk debit air yang terbaik terhadap kelangsungan hidup larva ikan lele dumbo (C.gariepinus.B) adalah perlakuan $\mathrm{D}(30 \mathrm{ml} /$ detik) yang menghasilkan persentase kelangsungan hidup yang paling tinggi yaitu $95.33 \%$.

Sementara debit air yang terbaik terhadap pertumbuhan panjang dan berat rata rata larva ikan lele dumbo (C. gariepinus. $B)$ adalah perlakuan $\mathrm{D}(30 \mathrm{ml} /$ detik) yang menghasilkan pertumbuhan panjang rata - rata $2.978 \mathrm{~cm} /$ ekor dan berat rata - rata 2.078 g/ekor.

\section{DAFTAR PUSTAKA}

Afrianto dan Liviawaty. E. 1988. Beberapa Metode Budidaya Ikan. Kanasius. Yogyakarta

Barus,T.A. 2002. Pengantar Limnologi. Universitas Sumatera Utara. Medan.

Breet, J.R. 1979. Environmental factors and growth. In: W.S. Hoar; O.J. Randal and J.R. Breet (Edotors). Fish Physiology, Vol, VIII. New York: Academic Press, hal. 599-675.

Boyd. 1990. Water Quality in Ponds for Aquaculture, Birmingham Publishing Co., Birmingham, Alabama, USA.

Chou, L.M. 1994. Growth of Hybrid Catfhishes Under Different Supplemental Diets. The Third Asian Fishes Forum. Asian Fisheries Society, Manila, Philippines. pp. 633-636..

[DJPB] Direktorat Jenderal Perikanan Budidaya. 2011. Usaha budidaya lele dan gurami saat ini. http://www.perikanan-budidaya.kkp.go.id [15 Mei 2011].

Effendi, I. 2004. Pengantar Akuakultur. Penebar Swadaya, Jakarta.

Effendie, M.I. 1979. Biologi Perikanan. Yayasan Pustaka Nusatama. Yogyakarta.

Effendi. H. 2000. Telaa Kualitas Air. Jurusan Manajemen Sumber Daya Peraiaran. Fakultas Perikanan Dan Ilmu Kelautan. IPB.

Forteath, N., Wee, L. and Frith, M., (1993), Water Quality, in P. Hart and O'Sullivan (eds) Recirculation System : Design, Construction and Management, University of Tasmania at Launceston, Australia.

Fransisca. W. 2014. Pengkayaan Cacing Tubifek Dengan Vitamin C Terhadap Kelangsung Hidup Danpertumbuhan Benih Ikan Lele Dumbo (Clariasgariepenus, B). Program Studi Budidaya Perairan Fakultas Pertanian. Universitas Batanghari jambi. Skripsi

Helfrich, L. A. and Libey, G., (2000), Fish Farming In Recirculating System (RAS), Departement of Fisheries and Wildlife Sciences, Virginia.

Hidayat, R. 2008. Pertumbuhan dan kelangsungan hidup benih ikan tambakan dengan kombinasi pakan yang berbeda. Skripsi. Universitas Riau.

Kelabora dan Sabariah. 2010. Tingkat pertumbuhan dan kelangsungan hidup larva ikan bawal air tawar (Collosoma sp.) dengan laju debit air berbeda pada sistem resirkulasi. Jurnal Akuakultur Indonesia 9 (1), 56-60 (2010). 
Jurnal Akuakultur Sungai dan Danau Vol. 1 No. 1 Tahun 2016 Hal 22 - 31

ISSN Online 2503-4766

Madinawati. N.S dan Yoel. 2011. Pemberian pakan yang berbeda terhadap pertumbuhan dan kelangsungan hidup benih ikan lele dumbo (Clarias gariepinus). Media Litbang Sulteng.

Najiyati. 1992. Morfologi Ikan Lele Lokal. Teknologi Budidaya. Bogor.

Rukmana, H.R. 2003. Budidaya dan Pascapanen Lele Dumbo. CV. Aneka Ilmu Anggota IKAPI. Semarang.

Saanin, H. 1968. Taksonomi dan Kunci Identifikasi Ikan Jilid I dan II. Bandung: Bina Cipta.

Setianawaty A. 2005. Pemanfaatan larutan nutrient pada pentongkolan udang galah Macrobrachium rosenbergii dikolam. [Skripsi]. Program Studi Teknologi dan Manajemen Akuakultur. Fakultas Perikanan dan Kelautan, Institut Pertanian Bogor.

Steel RGD, Torrie JH. 1991. Prinsip dan Prosedur Statistika. Jakarta: PT.Gramedia.

Suantika, G. 2001. Development of a Recirculation System for The Mass Culturing of The Rotifer Brachionus plicatilis, Ph. D Thesis in Applied Biological Science, Universiteit Gent, Belgium

Subandiyono, Nisrinah Dan Elfitasari. 2013. Pengaruh Penggunaan Bromelin Terhadap Tingkat Pemanfaatan Protein Pakan Dan Pertumbuhan Lele Dumbo (Clarias Gariepinus).

Suresh, A. V. and Lin, C. K., (1992), Effect of Stocking Density on Water Quality and Production of Red Tilapia in Recirculated Water System, Aquacultural Engineering, 11: 1-22.

Tai, C, J,J. Liu, N. S. SHEW, T. W. HUANG and L.G. LIN. 1979. The Efect of methods of forced molthing on reproductive performance of ducks. J. Taiwan Livestock Res 12(2); 19-26

Yamagata Y, Niwa M. 1982. Acute and choronic toxicity of ammonia to ell Anguilla japonica. Bull.Jap. Soc. Sci.Fish. 48 (2), 171-176

Zonneveld. N, E. A. Huisman, J. H. Boon. (1991). Prinsip-prinsip budidaya ikan. Gramedia Pustaka Umum. Jakarta 